\title{
Akt activation by human T-cell leukemia virus tax oncoprotein
}

\author{
Mathew Cherian', Hicham Baydoun', Jacob Al-Saleem², Mamuka Kvaratskhelia², Patrick Green², Lee Ratner ${ }^{1 *}$ \\ From 17th International Conference on Human Retroviruses: HTLV and Related Viruses \\ Trois Ilets, Martinique. 18-21 June 2015
}

Human T-Cell Leukemia Virus type 1 (HTLV-1), the etiological agent of Adult T-Cell Leukemia, expresses the viral oncoprotein Tax1. In contrast, HTLV-2, which expresses Tax2, is non-leukemogenic. One difference between these homologous proteins is the presence of a C-terminal PDZ (post synaptic density protein) domain binding motif (PBM), previously reported to be important for non-canonical nuclear factor kappa B (NFkappaB) activation. In contrast, the current study finds no defect in non-canonical NFkap$\mathrm{paB}$ activity by deletion of the Tax1 PBM. Instead, Tax1 PBM was found to be important for Akt (Protein Kinase B) activation. Tax1 attenuated the effects of negative regulatory phosphatases of the PI3K-AktmTOR pathway, PTEN (Phosphatase and Tensin homologue) and PHLPP (PH domain and leucine rich repeat protein phosphatase). Tax1 competes with PTEN for binding to PDZ protein DLG-1 (Drosophila disc large tumor suppressor), unlike a PBM deletion mutant of Tax1. Forced membrane expression of PTEN or PHLPP, by fusion to a myristolyation acceptor motif, overcame the effects of Tax1, as measured by levels of Akt phosphorylation at T308 and S473, and rates of Akt dephosphorylation. The current findings suggest that Akt activation may explain the differences in transforming activity of HTLV-1 and -2 . Moreover, these findings suggest a new approach to therapeutics for HTLV-1 lymphoproliferative disease. Supported by NIH grants CA94056, CA1730, CA63413, Lymphoma Leukemia Society grant 6067-10, American Society for Hematology fellowship and NIH T32 grant HL07088, and Lymphoma Research Foundation grant 307181203.

* Correspondence: Iratner@dom.wustl.edu

'Division of Oncology, Washington University, St Louis, MO, USA

Full list of author information is available at the end of the article
Authors' details

'Division of Oncology, Washington University, St Louis, MO, USA. ${ }^{2}$ Center for Retrovirus Research, The Ohio State University, Columbus, OH, USA.

Published: 28 August 2015

doi:10.1186/1742-4690-12-S1-P54

Cite this article as: Cherian et al:: Akt activation by human T-cell

leukemia virus tax oncoprotein. Retrovirology 2015 12(Suppl 1):P54.
Submit your next manuscript to BioMed Central and take full advantage of:

- Convenient online submission

- Thorough peer review

- No space constraints or color figure charges

- Immediate publication on acceptance

- Inclusion in PubMed, CAS, Scopus and Google Scholar

- Research which is freely available for redistribution
() Biomed Central 